\title{
The Growing Rift between Workers and Environmentalists
}

\author{
Erik Loomis
}

In 2013, I attended a symposium that brought leading environmentalists from around the country to Harvard University for a discussion about the failure of the cap and trade bill to pass during President Obama's first administration and to consider next steps. At the dinner that evening, speaker after speaker expressed despair and confusion. For decades, environmentalists relied on a combination of political popularity and scientific accuracy to lobby lawmakers to implement environmental legislation. But now that strategy had suddenly proven ineffective. The hostility of nearly all congressional Republicans to any legislative action on climate change left these environmentalists despondent and at a loss for solutions. As a labor activist as well as an environmental historian, this conversation reminded me of any number of union conferences I have attended, where a once powerful movement has no answers for navigating the political wilderness where it has suddenly found itself.

Support for environmentalism has declined precipitously since the 1970s and 1980s. In a 2000 Gallup poll, Americans answered a question about supporting environmental protection over economic development by a 70-23 margin. Answering the same question in 2013, respondents chose economic development $48-43 .{ }^{1}$ Part of this shift derives from a growing rift between workers and environmentalists, who had in the past formed tenuous but often very real alliances to combat pollution, improve workplace environments, and protect wilderness. ${ }^{2}$ Today, unions and environmentalists remain connected in the fight against increasingly unchecked corporate power, but more and more they seem inherently opposed to each other's goals. Building trade unions such as the Laborers International Union of North America (LIUNA) unite with oil companies against environmentalists and meet with President Trump to support oil pipelines. Many Northwestern timber workers blame the protection of the northern spotted owl for their job losses. Environmental activists themselves have helped to worsen this growing divide. The popular movement they built during the 1960s and 1970s has been largely abandoned in favor of the pursuit of a new strategy, centered on fundraising and lawsuits, one that does not nurture or depend upon a broad political base.

The history of the International Woodworkers of America (IWA) illustrates this shift. Between 1937 and 1987, the IWA, a Congress of Industrial Organizations (CIO)-affiliated timber workers' union, largely operating in the Pacific Northwest and western Canada, opposed the timber industry's logging practices, lambasting it for deforestation and community destabilization. In the late 1940s, the union lobbied for a congressional bill to regulate private forestry, end clearcutting, and demand sustainable forestry. Its representatives testified for wilderness bills in the 1950s, justifying the loss of productive timberland as necessary to provide recreation for its

\footnotetext{
1"Environment," Gallup News, http://www.gallup.com/poll/1615/environment.aspx (accessed Oct. 31, 2017).

${ }^{2}$ Robert Gordon, “'Shell No!' OCAW and the Labor-Environmental Alliance," Environmental History 3, no. 4 (Oct. 1998): 460-87; Fred Rose, Coalitions across the Class Divide: Lessons from the Labor, Peace, and Environmental Movements (Ithaca, NY, 2000); Brian K. Obach, Labor and the Environmental Movement: The Quest for Common Ground (Cambridge, MA, 2004); Scott Dewey, "Working for the Environment: Organized Labor and the Origins of Environmentalism in the United States, 1948-1970," Environmental History 3, no. 1 (Jan. 1998): 45-63.

(c) The Author(s) 2018. Published by Cambridge University Press
} 
members. In the 1970s, the IWA worked with greens to implement the Occupational Safety and Health Administration (OSHA) and continued to support environmental legislation. But in 1987, facing increasing pressure from job losses due to a cluster of factors that included log export policy, the depletion of old-growth forests, automation, and, to a lesser extent, environmental protection, IWA members revolted against their leadership and elected a new president who turned the union away from environmentalists, who they claimed stole their jobs, and toward an alliance with employers instead. ${ }^{3}$

Looking at changes in the environmental movement from a labor perspective sheds light on environmentalism's recent political decline and suggests five interlocking reasons why it has lost the power it had in the 1970s. First, to some extent, environmentalism is a victim of its own success. In the mid-twentieth century Americans saw, smelled, tasted, heard, and felt a degraded environment every day. The Pittsburgh smoke, the Los Angeles smog, the burning Cuyahoga River, and the everyday pollution that made the famed Crying Indian ad so popular touched the lived experiences of all kinds of Americans. Visits to the national forests also spiked in the decades after World War II, at the same time that those forests were being cut for timber production. This greatly influenced a generation of young environmental activists coming of age by the late 1960s. Union members, too, reacted to the growing degradation. Even though the mills where its members worked contributed to this pollution, the IWA supported new water pollution restrictions on Oregon's Willamette River, while testifying in favor of wilderness protection. This broad-based support for environmentalism led to a wide swath of legislation including successive Clean Air and Clean Water Acts, the Wilderness Act, the creation of the Environmental Protection Agency (EPA), the ban on DDT, and much else. This profoundly changed the nation. Most Americans under the age of fifty simply have not lived in a truly degraded environment, and thus the movement seems less vitally connected to their daily lives than it had in $1970 .^{4}$

Second, the structural transformation of the American economy beginning in the 1970s undermined the prosperity that once enabled working-class environmental demands. The recession and oil crisis that stymied growth beginning in 1973 eventually faded, but deindustrialization, outsourcing, capital mobility, and the increased centrality of finance to the economy had far-reaching impacts that continue to shape politics today. Real income stagnated, union membership declined, and increased profits from improved productivity went almost exclusively into the pockets of executives and shareholders. Union support for environmental legislation dried up when employers threatened to shutter and move factories. ${ }^{5}$ Economic instability made environmentalism a luxury workers felt they could not afford. In the IWA, for example, this led to a grassroots revolt during the union's 1978 convention over its support for an expanded Redwood National Park. Those union leaders still committed to working with environmentalists had to tread cautiously as factories closed and union membership dropped sharply in the 1980s. ${ }^{6}$

Third, the rise of the modern conservative movement provided funding and organization to counteract the claims made by environmentalists. Although overstated as a transformative moment, the 1971 Powell Memo, when future Supreme Court justice Lewis Powell wrote to

\footnotetext{
${ }^{3}$ Erik Loomis, Empire of Timber: Labor Unions and the Pacific Northwest Forests (New York, 2016).

${ }^{4}$ Robert Gottlieb, Forcing the Spring: The Transformation of the American Environmental Movement, rev. ed. (Washington, DC, 2005); Kirkpatrick Sale, The Green Revolution: The American Environmental Movement, 1962-1992 (New York, 1993); Philip Shabecoff, A Fierce Green Fire: The American Environmental Movement, rev. ed. (Washington, DC, 2003).

${ }^{5}$ Richard Kazis and Richard L. Grossman, Fear at Work: Job Blackmail, Labor, and the Environment (New York, 1982).

${ }^{6}$ Jefferson Cowie, Stayin' Alive: The 1970s and the Last Days of the Working Class (New York, 2010); Judith Stein, Pivotal Decade: How the United States Traded Factories for Finance in the Seventies (New Haven, CT, 2010); Erik Loomis, Out of Sight: The Long and Disturbing Story of Corporations Outsourcing Catastrophe (New York, 2015).
} 
the U.S. Chamber of Commerce urging corporations to fight back against liberalism, coincided with the growth of a newly robust corporate agenda. The Sagebrush Rebellion, a movement in the rural West in the late 1970s and early 1980s that called for a rejection of environmentalism and a return of public lands to the states for mining, logging, and grazing development, similarly helped to create the political narratives by which rural western politicians frame themselves today. It also gave natural resource workers a clear target to blame for their suddenly precarious position in the economy. Workers in the timber, agricultural, fishing, ranching, and fossil fuel industries heard a steady stream of misinformation from their employers about environmentalists costing them their jobs, even as most lost their jobs thanks to corporate mismanagement of natural, financial, and human resources. Even as both greens and union leaders blamed log export policy and automation for unemployment, the IWA rank-and-file turned to blaming "outsiders" for their plight, whether the head of the Sierra Club, environmentalists in general, Portland residents, or students at the University of Oregon. ${ }^{7}$ Meanwhile at the federal level, Reagan administration appointees, such as Secretary of Interior James Watt and EPA director Anne Gorsuch, opened a new era of hostility.

Fourth, environmentalists responded to the hostile political climate of the 1980s with a focus on fundraising and defending environmental legislation in court-decisions that are hard to criticize but nevertheless had negative consequences. The legal strategy saved species such as the northern spotted owl, as well as the last ancient forests in the Northwest where they reside. But it cost a lot of money and, by centering campaigns around glossy pictures of polar bears and the Amazon rain forest rather than fundraising to fight polluting factories and urban poverty, this strategy reinforced a growing public perception of environmentalism as an elite movement. Northwest timber workers seeing their jobs disappear may have been duped by their employers to blame environmentalists, but the collapse of green connections to unions, including the IWA, made any meaningful bridge building impossible and, by and large, the environmental groups involved in the ancient forest campaigns had little interest anyway. ${ }^{8}$

Fifth, environmentalists have failed to articulate a vision for working-class economy in a post-industrial, multicultural United States. Environmentalism has developed a cozier relationship with green capitalists than with everyday employees. A green energy capitalist is still a capitalist and desires to limit labor costs to increase profit. Environmentalists have had little to say about the future of unions, American manufacturing, or the decline of the middle class. Until environmentalists can persuade working and middle-class Americans that their movement and issues such as climate change are vitally connected to their daily lives, they will likely continue struggling to regain political momentum. ${ }^{9}$ Environmentalists have meanwhile struggled to build strong alliances with communities of color. In the nearly three decades since the 1990 letter penned by environmental justice organizations accusing Big Greens of marginalizing or ignoring people of color, localized movements, such as the Dakota Access Pipeline campaign, which united Native Americans protecting their homelands with white activists, have shown the potential for such collaboration, and some organizations such as the Sierra Club

\footnotetext{
${ }^{7}$ Kim Phillips-Fein, Invisible Hands: The Making of the Conservative Movement from the New Deal to Reagan (New York, 2009); Christopher McGrory Klyza, Who Controls Public Lands? Mining, Forestry, and Grazing Policies, 1870-1990 (Chapel Hill, NC, 1996); John D. Echeverria and Raymond Booth Eby, eds., Let the People Judge: Wise Use and the Private Property Rights Movement (Washington, DC, 1995).

${ }^{8}$ James Morton Turner, The Promise of Wilderness: American Environmental Politics since 1964 (Seattle, 2012); Douglas Bevington, The Rebirth of Environmentalism: Grassroots Activism from the Spotted Owl to the Polar Bear (Washington, DC, 2009); Christopher McGrory Klyza and David J. Sousa, American Environmental Policy, 1990 2006: Beyond Gridlock (Cambridge, MA, 2007); Darren Frederick Speece, Defending Giants: The Redwood Wars and the Transformation of American Environmental Politics (Seattle, 2016).

${ }^{9}$ Erik Loomis, “Towards a Working-Class Environmentalism,” New Republic, Dec. 5, 2016, https://newrepublic. com/article/139132/towards-working-class-environmentalism (accessed Oct. 31, 2017).
} 
have dedicated staff and resources to becoming important allies of environmental justice activists. ${ }^{10}$ But real organizing and awareness of the pressing issues facing communities of color from the larger environmental movement remain slight and, both in terms of popular perception and active membership, the movement remains largely white and prosperous.

In short, environmentalism's decreasing popularity stems from a combination of structural economic transformations, political developments, and shifts within the environmental movement itself away from popular mobilization toward an embrace of elites. An old adage of union organizing is that you have to meet people around the issues that are important to them, not that are important to you. Environmentalism, too, becomes much less of a hard sell when it touches people's lives-when it is focused on building a movement based around the daily needs of working people. Such campaigns are absolutely necessary if environmentalism is to once again become the popular and powerful movement that once led to sweeping legislation which transformed the nation.

Erik Loomis is associate professor of history at the University of Rhode Island. He is the author of Empire of Timber: Labor Unions and the Pacific Northwest Forests (New York, 2016) and Out of Sight: The Long and Disturbing Story of Corporations Outsourcing Catastrophe (New York, 2015). His latest book, A History of America in Ten Strikes, will be published by The New Press in October 2018. He writes about labor, environment, and politics at the blog Lawyers, Guns, and Money.

\footnotetext{
${ }^{10}$ Robert D. Bullard, Dumping in Dixie: Race, Class, and Environmental Quality (Boulder, CO, 1990); Luke W. Cole and Sheila R. Foster, From the Ground Up: Environmental Racism and the Rise of the Environmental Justice Movement (New York, 2001); Robert D. Bullard, ed., Unequal Protection: Environmental Justice and Communities of Color (San Francisco, 1994).
} 